\title{
Research Progress of the Antiviral Bioactivities of Natural Flavonoids
}

\author{
Lin Wang $^{1} \cdot$ Junke Song ${ }^{1} \cdot$ Ailin $\mathrm{Liu}^{1} \cdot$ Bin Xiao ${ }^{2} \cdot$ Sha $^{\mathrm{Li}^{1}} \cdot$ Zhang Wen $^{1} \cdot$ Yang Lu ${ }^{1} \cdot$ Guanhua Du ${ }^{1}$
}

Received: 22 May 2020 / Accepted: 24 June 2020 / Published online: 18 September 2020

(c) The Author(s) 2020

\begin{abstract}
Flavonoids are now considered as an indispensable component in a variety of nutraceutical and pharmaceutical applications. Most recent researches have focused on the health aspects of flavonoids for humans. Especially, different flavonoids have been investigated for their potential antiviral activities, and several natural flavonoids exhibited significant antiviral properties both in vitro and in vivo. This review provides a survey of the literature regarding the evidence for antiviral bioactivities of natural flavonoids, highlights the cellular and molecular mechanisms of natural flavonoids on viruses, and presents the details of most reported flavonoids. Meanwhile, future perspectives on therapeutic applications of flavonoids against viral infections were discussed.
\end{abstract}

Keywords Antiviral bioactivities · Natural flavonoids · Cellular and molecular mechanisms · Therapeutic applications

\section{Introduction}

Flavonoids comprise one of the largest groups of secondary metabolites found in biologically active plants, including vegetables, fruits, seeds, nuts, wine, and tea. Flavonoids are low molecular weight compounds with a simple 15 carbon backbone, and there are more than 9000 varieties of flavonoids that have been structurally identified. The natural flavonoids are an important source of medicines [1].

Typically, flavonoids are divided into flavones, flavonols, flavanones, flavanonols, flavanes, flavanols, chalcones, anthocyanidins, aurones, isoflavones, biflavones [2]. The carbon atoms in flavonoid molecules are assembled in two benzene rings, commonly denoted as $\mathrm{A}$ and $\mathrm{B}$, which are connected by an oxygen-containing pyrene ring. A common

Congratulations to Academician Sun Handong for his outstanding scientific achievements and contributions. I sincerely thank him for his support and care for my work, and wish Professor Sun a happy eightieth birthday! Health and longevity!

Guanhua Du

dugh@imm.ac.cn

1 Beijing Key Laboratory of Drug Targets Identification and Drug Screening, Institute of Materia Medica, Chinese Academy of Medical Sciences and Peking Union Medical College, 1 Xian Nong Tan Street, Beijing 100050, China

2 Laboratory of Clinical Pharmacy, Ordos Central Hospital, Ordos School of Clinical Medicine, Inner Mongolia Medical University, Ordos 017000, China part of the chemical structure of all flavonoids is the carbon skeleton based on the flavan system (C6-C3-C6) (Fig. 1). Aurone is a type of flavonoid with a heterocyclic ring containing a benzofuran element while biflavonoids are dimers of flavonoid moieties linked by a $\mathrm{C}-\mathrm{C}$ or $\mathrm{C}-\mathrm{O}-\mathrm{C}$ bond. Condensation of $\mathrm{A}$ and $\mathrm{B}$ ring leads to the formation of chalcone, which undergoes cyclization involving isomerase and forms flavanone, the initial compound for the synthesis of other group flavonoids [3]. Although the various classes of flavonoids possess different structures, all flavonoids appear multi-bioactivities and complex roles in the system of biology.

Most flavonoids, except for the subclass of catechins, are present in plants bound to sugars as $\beta$-glycosides. The common sources of natural flavones were the vegetables such as Chamomile tea (Matricaria chamomilla), leaves of parsley (Petroselinum crispum), celery (Apium graveolens) and spinach (Spinacia oleracea), roots of plants, propolis, and honey and so on [4]. Even the flavonoids could obtain from various of food and vegetables, the molecules with different structures are of different bioactivities. Since the first report in 1938, flavonoids were described as a broad spectrum of biological activities such as anti-inflammation, antioxidant, antibacterial, antiviral, anticancer, and neuroprotection [5]. In this review, we made a literature retrieval for the anti-virus activity of flavonoids. The antiviral activity of flavones was studied and reported from the 1990s, when apigenin showed synergistic effects to acyclovir on herpes 
<smiles>c1ccc(C2CCc3ccccc3O2)cc1</smiles>

(B)<smiles>c1ccc(-c2cc3ccccc3o2)cc1</smiles>

(C)

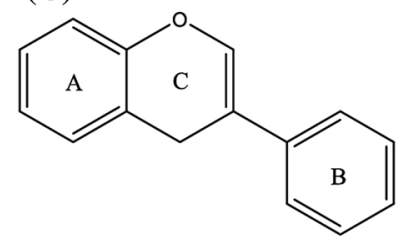

(D)

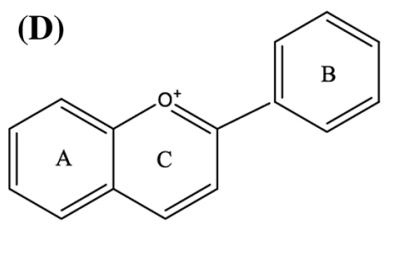

Fig. 1 The basic scaffolds of flavonoids. a The scaffold of flavanones and catechins; $\mathbf{b}$ the scaffold of the flavones and flavonols; $\mathbf{c}$ the scaffold of isoflavone; $\mathbf{d}$ the scaffold of anthocyanins. The structures of aurones and biflavones were not involved in this figure since their structures containing some special elements which were described in the article

simplex virus types 1 and 2 (HSV-1 and HSV-2) in cell culture. Recently, flavones are reported the inhibitory activity on viruses, including A/FM1/1/47(H1N1), H3N2, H5N1 (strain A/Thailand/Kan-1/04), HBV, HCV, HIV, dengue virus (DENV-2), Sendai virus, Zika virus, Coxsackie virus (CVB3) and Japanese encephalitis virus (JEV) [6]. Especially, the latest study showed flavones efficiently inhibited SARS-CoV [7]. However, numerous positive findings have been reported on the in vitro efficacy of flavonoids, but less promising results have been obtained for most compounds in in vivo studies due to poor bioavailability of flavonoids. The low solubility of flavonoid aglycones in water, coupled with its short residence time in the intestine as well as its lower absorption, save humans from the acute toxic effects via the consumption of flavonoids, except for a rare occurrence of allergy [8]. Therefore, the efforts in enhancing the bioavailability of flavonoids upon intake by humans are vitally necessary in order to develop these natural compounds into potential antiviral drugs.

Generally speaking, the absorption of the dietary flavonoids liberated from the food will depend on their physicochemical properties such as molecular size, configuration, lipophilicity, solubility, and pKa [9]. In addition, flavonoid protein interactions are involved in flavonoid bioavailability. Depending upon structure, the flavonoid can be absorbed from the small intestine or has to go to the colon, where they are metabolized via microbial catabolism, conjugation in liver and enterocytes. Due to these conjugation reactions, no free flavonoid aglycones can be found in plasma or urine, except for catechins [10]. The sugar moiety of flavonoid glycosides is an important determinant of their bioavailability [11].

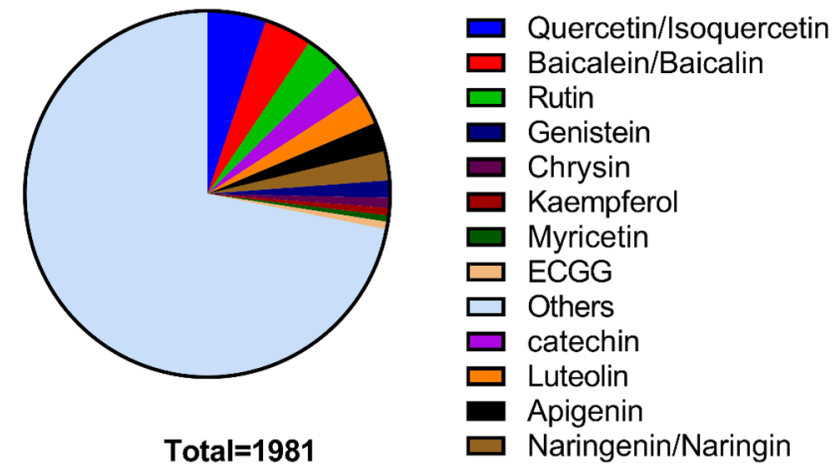

Fig. 2 Literature review on the antiviral activities of natural flavonoids

\section{Overview of the Research on the Antiviral Effects of Flavonoids}

Based on the literature published in the international journals, up to May 2020, more than 1000 researches on the anti-virus activities in vivo and in vitro and 100s of natural flavonoids have been tested in different viruses. But, only about decades were focused, such as coumarin, luteolin, and so on (Fig. 2).

Generally, all the bioactivities found in the flavonoids could be summarized to some main aspects. Flavonoids, including genistein, catechins, and so on, have been shown to reduce the infectivity of a variety of viruses affecting humans and animals, including adenovirus, HSV, HIV, porcine reproductive and respiratory syndrome virus, and rotavirus [12]. Current results about the mechanisms of action underlying their antiviral properties suggest a combination of effects on both the virus and the host cell. Flavonoids have been reported to affect virus adsorption, entry, replication, viral protein translation, the formation of certain virus envelope glycoprotein complexes, and virus release [13-16]. They also affect a variety of host cell signaling processes, including induction of gene transcription factors and secretion of cytokines $[17,18]$. Although enormous promising results were from in vitro experiments, a few in vivo results can partly confirm their in vivo efficacy. Flavonoids possess antiviral properties against a wide range of viruses under both in vitro and in vivo conditions (Table 1).

\section{Mechanism of Antiviral Flavonoids}

In many cases, DNA viruses utilize cellular enzymes for synthesis of their DNA genomes and mRNAs; all viruses utilize normal cellular ribosomes, tRNAs, and translation factors for the synthesis of their proteins. Most viruses commandeer the cellular machinery for macromolecular 
Table 1 The different viruses which inhibited by various flavonoids

\begin{tabular}{|c|c|c|c|}
\hline Viruses & Model & Flavonoids & References \\
\hline Influenza virus & MDCK cells & $\begin{array}{l}\text { Gallocatechin-7-gallate, catechins, apigenin, luteolin, } \\
\text { 3-deoxysappanchalcone, scutellarin, galuteolin, vitexin, } \\
\text { chrysin, kaempferol, quercetin, myricetin, rhamnocitrin, } \\
\text { rutin, daidzein, genistein, sappanchalcone, baicalein, } \\
\text { oroxylin A }\end{array}$ & $\begin{array}{l}\text { Liu et al. [19], } \\
\text { Yonekawa et al. } \\
\text { [20] }\end{array}$ \\
\hline HBV & Vero cells & 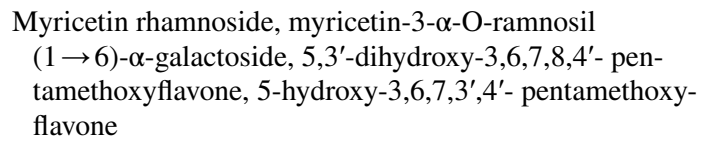 & Ortega et al. [21] \\
\hline $\mathrm{HCV}$ & Huh-7.5 cells & Epigallocatechin gallate (EGCG), sorbifolin, pedalitin & Mekky et al. [22] \\
\hline HIV-1 & $\mathrm{CD}^{+}{ }^{+} \mathrm{NKT}$ cells, $\mathrm{T}$ cells & $\begin{array}{l}\text { Hesperidin, linarin, catechins, genistein, herbacitrin, } \\
\text { naringin, formononetin, biochanin A }\end{array}$ & Nzuza et al. [23] \\
\hline HIV-2 & Vero cells & Genistein, formononetin, biochanin A & Patra [24] \\
\hline HSV-1 & Vero and CV1 cells & $\begin{array}{l}\text { Catechins, genistein,gorvanol A, kaempferol, 5,6,7-tri- } \\
\text { methoxyflavone, 5,3'-dihydroxy-3,6,7,8,4'- pentameth- } \\
\text { oxyflavone, 5-hydroxy-3,6,7,3',4'- pentamethoxyflavone, } \\
\text { coumestrol, houttuynoid A, chrysin }\end{array}$ & Li et al. [25] \\
\hline HSV-2 & Vero cells & Genistein, coumestrol, houttuynoid A & Bús et al. [26] \\
\hline HPV-1 & Human condyloma, Vero cells & $\begin{array}{l}\text { Catechins, 5,3'-dihydroxy-3,6,7,8,4'- pentamethoxyfla- } \\
\text { vone, 5-hydroxy-3,6,7,3',4'- pentamethoxyflavone }\end{array}$ & Patra [24] \\
\hline DENV-2 & $\begin{array}{l}\text { C6/36 } \\
\text { Aedes albopictus mosquito cell, } \\
\text { hepatocytes (Huh-7) }\end{array}$ & Quercetin, quercitrin, kaempferitrin, chrysin & Patra [24] \\
\hline Sendai virus $(\mathrm{SeV})$ & Mice model & Baicalein & Dou et al. [27] \\
\hline Zika virus (ZIKV) & Vero cells & $\begin{array}{l}\text { Baicalein, baicalin, pinocembrin, chrysin, myricetin, } \\
\text { luteolin, Epigallocatechin gallate, epicatechin gallate, } \\
\text { gallocatechin gallate, quercetin-3- } \beta \text {-O-D-glucoside }\end{array}$ & Oo et al. [28] \\
\hline CVB3 & Vero cells & $\begin{array}{l}\text { Mosloflavone, oroxylin A, norwogonin, epigallocatechin- } \\
\text { 3-gallate }\end{array}$ & Patra [24] \\
\hline JEV & A549 cells, BHK21 cells & Epigallocatechin-3-gallate (EGCG), luteolin, kaempferol & Patra [24] \\
\hline EBV & Ramos cells & Genistein, quercetin, apigenin, luteolin, baicalein & Granato et al. [29] \\
\hline Poliovirus & Vero cells & $\begin{array}{l}\text { 5,6,7-Trimethoxyflavone, 3-methylkaempferol, } 3(2 \mathrm{H}) \text { - } \\
\text { isoflavene }\end{array}$ & Ortega et al. [21] \\
\hline RSV & Vero cells & $\begin{array}{l}\text { Genistein, quercetin, baicalein, baicalin, epigallocatechin- } \\
\text { 3-gallate, proanthocyanidin }\end{array}$ & Zhang et al. [30] \\
\hline Coronovirus & Vero cells & $\begin{array}{l}\text { Quercetin, Luteolin, quercetin, quercetrin, kaempferol } \\
\text { glycosides }\end{array}$ & Patra [24] \\
\hline SARS-CoV & $3 \mathrm{CL}$ protease activity assay & $\begin{array}{l}\text { Daidzein, rutin, genistein, icaritin, genistin, ipriflavone, } \\
(-) \text { gallocatechin, }( \pm) \text {-epigallocatechin gallate, puerarin, } \\
\text { (-)-epicatechin, glabridin, }( \pm) \text {-catechin, baicalein, dios- } \\
\text { min, diosmetin, skullcapflavone II, orientin, acacetin, } \\
\text { bacicalin, rhoifolin, hispidulin, sinensetin, oroxin B, } \\
\text { pectolinarin, cirsiliol, homoplantaginin, amentoflavone, } \\
\text { luteolin, herbaacetin, kaempferol, morin, myricetin, } \\
\text { fisetin, quercitrin, queretin, helichrysetin, cardamonin, } \\
\text { neodesperidin dishydrochalcone, mangiferin, auraptene }\end{array}$ & Jo et al. [7] \\
\hline Human CMV & HEL 299 cells & Genistein, 5,6,7-Trimethoxyflavone & Patra [24] \\
\hline Rotavirus & MA-104 cells, Caco 2 cells & $\begin{array}{l}\text { Genistein, epigallocatechin Gallate (EGCG), } \alpha \text {-glucosyl } \\
\text { hesperitin }(\mathrm{GH})\end{array}$ & Lipson et al. [31] \\
\hline Adenovirus & Hep2 cells, SW480 cell, BCC-1/KMC cells & Catechins, genistein, quercetin & Patra [24] \\
\hline SARS-CoV-2 & Vero cells & $\begin{array}{l}\text { Baicalein, scutellarein, dihydromyricetin, quercetagetin, } \\
\text { myricetin }\end{array}$ & Liu et al. [32] \\
\hline
\end{tabular}


synthesis during the late phase of infection, directing it to synthesize large amounts of a small number of viral mRNAs and proteins instead of normal cellular macromolecules. The lytic cycle of viral replication includes adsorption, penetration, replication, and release [33] (Fig. 3). The outcome is the production of a new round of viral particles and the death of the cell. According to the lytic cycle of the virus, antiviral drugs can be categorized into the inhibitors of fusion, uncoating, nucleic acid synthesis, integration, protease, and release. Targeting chemokine receptors and glycoprotein (GP)-receptor interactions are also of the most attractive candidates to inhibit viral entry/fusion. Especially, viral enzymes, including RNA polymerase, DNA polymerase, and reverse transcriptase, were considered as alternative targets in many viral infections such as $\operatorname{HBV}[34,35]$. In addition to previously described viral targets, new classes of antiviral drugs targeting host factors involved in virus replication, virus-cell interactions, and the immune response have been introduced [36].

Many reports on the antiviral activity of naturally occurring flavonoids are available. The structure-function relationship between flavonoids and their enzyme inhibitory activity has been observed. Baicalin was reported to interfere with the viral neuraminidase activity [37]. Flavan-3-o1 was more effective than flavones and flavonones in selective inhibition of HIV-1, HIV-2, and similar immunodeficiency virus infections. Baicalin inhibits HIV-1 infection and replication. Flavonoids such as demethylated gardenin A and robinetin are known to inhibit HIV-1 proteinase. It has also been reported that the flavonoids chrysin, acacetin, and apigenin prevent HIV-1 activation via a novel mechanism that probably involves inhibition of viral transcription [38,

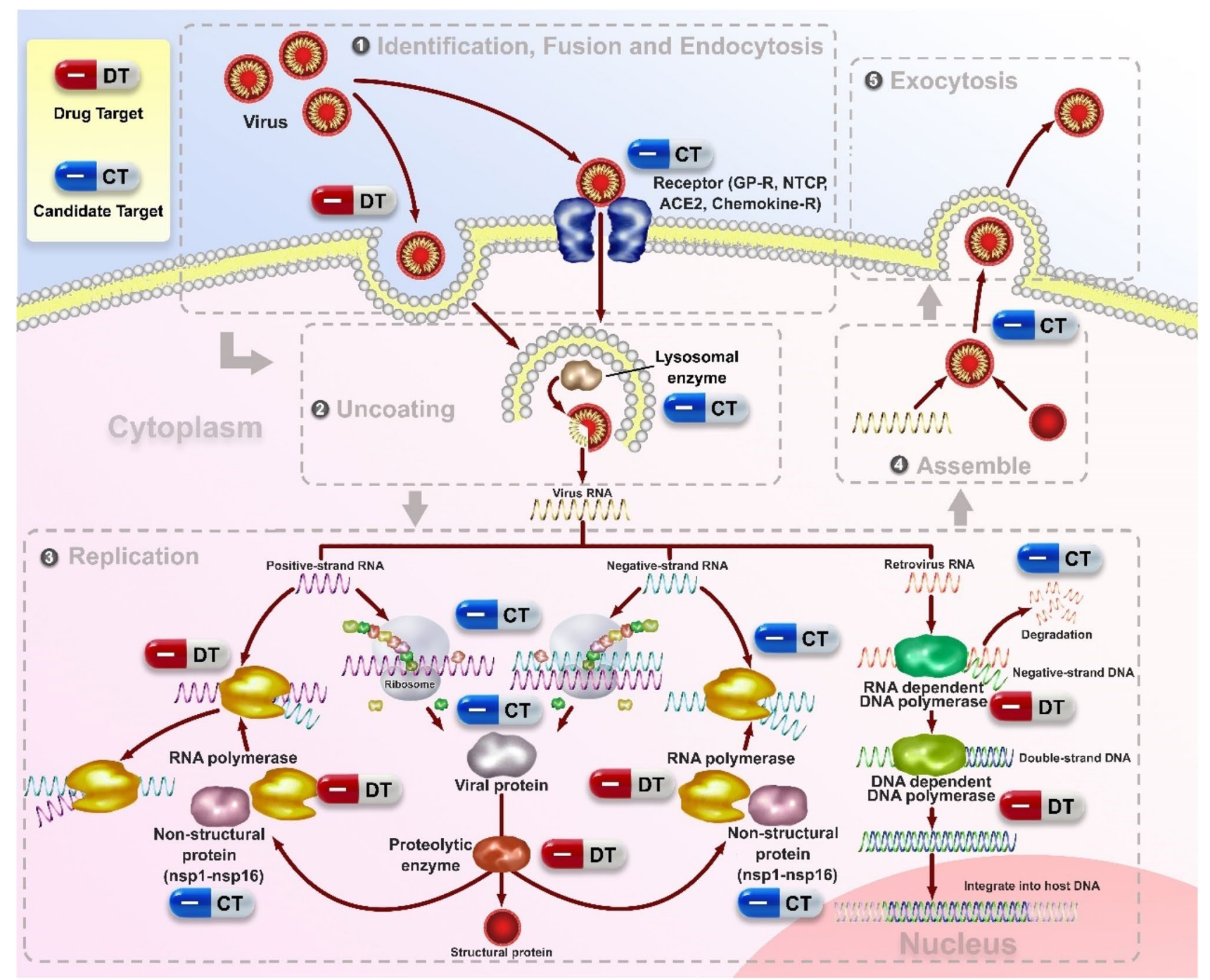

Fig. 3 Potential drug targets (DT) and candidate targets (CT) of flavonoids in the viral life cycle. The viral life cycle can be divided into a sequence of stages (attachment and entry; uncoating, replication, assemble, and exocytosis), each of which is a potential site for pharmacologic intervention. Here we showed potential drug targets (DT) and candidate targets (CT) of antiviral flavonoids 
39]. Various combinations of flavones and flavonols have been shown to exhibit antiviral synergism [21]. Kaempferol and luteolin show synergistic effects against herpes simplex virus (HSV). Synergism has also been reported between flavonoids and other antiviral agents. Quercetin is reported to potentiate the effects of 5-ethyl-2-dioxyuridine and acyclovir against HSV and pseudorabies infection [40]. Many flavonoids, namely, dihydroquercetin, dihydrofisetin, leucocyanidin, pelargonidin chloride, and catechin, show activity against several types of viruses, including HSV, respiratory syncytial virus, poliovirus, and Sindbis virus. Quercetin is reported to potentiate the effects of 5-ethyl-2-dioxyuridine and acyclovir against HSV and pseudorabies infection. Studies have displayed that flavonols are more active than flavones against herpes simplex virus type 1 , and the activity order from strong to weak was found to be galangin, kaempferol, and quercetin. Zandi et al. studied the anti-dengue virus properties of quercetin, hesperetin, naringin, and daidzein at different stages of DENV-2 (dengue virus type-2) infection and replication cycle [41]. Quercetin was found to be most effective against DENV-2 in cells. In addition, flavonoids were reported anti-inflammation by diminishing inflammatory response and excessive immune response [42]. Therefore, flavonoids protect host cells from damage induced by a viral infection. For instance, selected flavonoids can reduce complement activation, thereby decreasing the adhesion of inflammatory cells to the endothelium and, in general, resulting in a diminished inflammatory response. Another feature of flavonoids is a reduction in the release of peroxidase. This reduction inhibits the production of reactive oxygen species by neutrophils by interfering with 1 -antitrypsin activation and the metabolism of arachidonic acid $[41,43]$.

The flavonoids with anti-virus activities act on various targets, which are known targets with some anti-virus drugs. And some proteins and enzymes which some flavonoids interacted and include in the virus replications may be a candidate target for new anti-virus drugs. (Fig. 3).

\section{Important Antiviral Natural Flavonoids}

\subsection{Quercetin and Isoquercitin}

Quercetin is widely distributed in angiosperms such as Threevein Astere, Golden Saxifrage, berchemia lineata, gold, rhododendron dauricum, seguin loquat, purple rhododendron, Rhododendron micranthum, Japanese Ardisia Herb and Apocynum. Isoquercitin (IQ), a naturally occurring glycoside of quercetin also known as hirsutrin, isoquercetrin, quercetin3glucoside $(\mathrm{Q} 3 \mathrm{G})$, quercetin3OßBglucoside. Naturally occurring quercetin compounds are mainly glycosides such as IQ and are commonly found in plants and the human diet.

The quercetin and IQ differ in their structures, bioavailability, absorption, and biological actions. Quercetin and IQ have various kinds of pharmacological functions and are mainly used for treating clinical bronchitis and phlegmatic inflammation. Currently, quercetin/IQ are reported antiviral activities by many researchers (Table 2 ).

\subsection{Baicalein}

Scutellaria baicalensis Georgi is a medicinal plant with multiple pharmacological activities. Scutellaria baicalensis is the main component of Chinese patent medicine preparations for clinical use, such as Shuanghuanglian injection and Qingkailing injection. Baicalin and its active metabolite baicalein are the main pharmacologically active compounds in Scutellaria baicalensis. Modern research shows that baicalin has certain antiviral activity. Its antiviral pharmacological effect is a concrete manifestation of the heat-clearing and detoxifying effect in the classics of traditional Chinese medicine. With the development of research, details of the antiviral activities of baicalein were reported (Table 3 ).

\subsection{Apigenin}

Apigenin, a member of the flavone family, is a nontoxic and nonmutagenic dietary flavonoid found in parsley, artichoke, basil, celery, and other plants. Apigenin (4',5,7-trihydroxyflavone) contains a hydroxyl group in its B-ring, and hydroxyl groups in its $\mathrm{C}$-ring. The apigenin contained plants are used for the treatment of different diseases and infections like diabetes, dysentery, hepatitis, blennorrhagia, cancer arthritis, inflammation, woods, hemorrhoids, and leishmanial ulcers. Especially, apigenin exhibits various antiviral activities against numerous viruses in vitro and in vivo: enterovirus 71 (EV71), hepatitis $\mathrm{C}$ virus (HCV), Human Immunodeficiency Virus (HIV), and adenoviruses. Apigenin exerted inhibitory effects on HCV replication by decreasing mature miR122 expression levels. Apigenin also inhibited FMDV (Foot and mouth disease virus) infection by suppressing IRES-driven translational activity inhibited FMDV infection at the post-entry stage. Apigenin inhibits EBV reactivation into the lytic cycle and virion production by EBV-positive NPC cells. The antiviral activity of apigenin is currently reported, as shown in Table 4.

\subsection{Luteolin}

Luteolin (3,4,5,7-tetrahydroxyflavone) is a pure yellow crystal representing the category of bioflavonoid. It is abundant in various medicinal herbs, fruits, and vegetables, e.g., broccoli, onion, parsley, green peppers, citrus, celery, 
Table 2 Anti-virus activities of quercetin/IQ

\begin{tabular}{|c|c|c|c|}
\hline Virus & Mechanism of action & Dose/concentration & References \\
\hline A/Udorn/317/72 (H3N2) & $\begin{array}{l}\text { Decreases superoxide and LPO associated } \\
\text { viral infection }\end{array}$ & $1 \mathrm{mg} /$ day & Kumar et al. [44] \\
\hline Dengue virus & Inhibits virus replication & $20 \mathrm{mg} / \mathrm{mL}$ & Keivan Zandi et al. [43] \\
\hline Japanese encephalitis virus & $\begin{array}{l}\text { Inhibits virus adsorption; Interferes virus } \\
\text { replication }\end{array}$ & $\mathrm{IC}_{50}(212.1 \mu \mathrm{g} / \mathrm{mL})$ & Jefree Johari et al. [45] \\
\hline Rhinovirus & $\begin{array}{l}\text { Inhibits RV endocytosis and replication } \\
\text { and the expression of chemokines and } \\
\text { cytokines }\end{array}$ & $10 \mu \mathrm{M}$ in vitro; $0.2 \mathrm{mg} / \mathrm{kg}$ in vivo & Shyamala Ganesan et al. [46] \\
\hline Mayaro virus & Inhibits virus replication & $2 \mu \mathrm{g} / \mathrm{mL}$ & dos Santos et al. [47] \\
\hline $\mathrm{H} 1 \mathrm{~N} 1, \mathrm{H} 3 \mathrm{~N} 2$, and $\mathrm{H} 5 \mathrm{~N} 1$ & $\begin{array}{l}\text { Binds to Influenza hemagglutinin protein; } \\
\text { inhibit viral-cell fusion }\end{array}$ & $\begin{array}{l}\mathrm{IC}_{50}(7.756,6.225,2.738 \mu \mathrm{g} / \mathrm{mL} \\
\text { respectively) }\end{array}$ & Wu et al. [48] \\
\hline Epstein-Barr virus & $\begin{array}{l}\text { Induces EBV gene transcription; reduces } \\
\text { EBV latency; increases EBV progeny } \\
\text { production; inhibits EBV infection }\end{array}$ & $62 \mu \mathrm{M}$ & Lee et al. [49] \\
\hline hepatitis $C$ virus & $\begin{array}{l}\text { Inhibits HCV replication, specific infectiv- } \\
\text { ity; affects virion integrity; hampers the } \\
\text { localization of HCV core protein to LDs }\end{array}$ & $50 \mu \mathrm{M}$ & Ángela Rojas et al. [50] \\
\hline Influenza A H1N1 (A/PR/8/34) & Inhibits neuraminidase & $1.563 \mu \mathrm{g} / \mathrm{mL} ; 240 \mathrm{mg} / \mathrm{kg} /$ days & Liu et al. [51] \\
\hline
\end{tabular}

Table 3 Anti-virus activity of baicalin

\begin{tabular}{|c|c|c|c|}
\hline Virus & Mechanism of action & Dose/concentration & References \\
\hline A/FM1/1/47 (H1N1) & Interferes with neuraminidase activity & $1.2 \mu \mathrm{g} / \mathrm{mL}$ & $\mathrm{Xu}$ et al. [52] \\
\hline Strain A/Thailand/K (H3N2) & Inhibits virus budding and neuraminidases & IC50:49.6 $\pm 1.07 \mu \mathrm{g} / \mathrm{mL}$ & Gao et al. [3] \\
\hline an-1/04 (H5N1) & Interferes with $\mathrm{H} 5 \mathrm{~N} 1$ replication & IC50:18.79 $\pm 1.17 \mu \mathrm{M}$ & Sithisarn et al. [15] \\
\hline SARS-CoV & $3 \mathrm{CL}^{\text {pro }}$ & $0.39 \mu \mathrm{M}$ & Liu et al. (2020) \\
\hline Zika virus & Inhibits virus replication & $0.004 \mu \mathrm{M}$ & Oo et al. [28] \\
\hline Dengue virus & Inhibits virus replication & IC50:13.5 $\pm 0.08 \mu \mathrm{g} / \mathrm{mL}$ & Moghaddam et al. [53] \\
\hline Sendai virus & Interferes with neuraminidase & $0.70 \mu \mathrm{g} / \mathrm{mL}$ & Dou et al. [27] \\
\hline Japanese encephalitis virus & Interactions with the E protein of DENV2 & $14.28 \mu \mathrm{g} / \mathrm{mL}$ & Johari et al. [45] \\
\hline CVB3 & Inhibits virus replication & IC50:429.00 $\pm 22.06 \mu \mathrm{g} / \mathrm{mL}$ & Gao et al. [54] \\
\hline Japanese encephalitis virus & Direct virucidal activity & $14.28 \mu \mathrm{g} / \mathrm{mL}$ & Johari et al. [45] \\
\hline Human HIV-1 & $\begin{array}{l}\text { Inhibits HIV-1 induced syncytium formation, HIV-1 p24 } \\
\text { antigen, and HIV-1 RT production; inhibits Env-protein } \\
\text { mediated fusion of HIV }\end{array}$ & $4.3 \mu \mathrm{M}$ & Fesen et al. [55] \\
\hline DENV-2 & Inhibits virus replication & $1.55 \mu \mathrm{g} / \mathrm{mL}$ & Zandi et al. [45] \\
\hline
\end{tabular}

and chamomile. Luteolin has many beneficial properties, including antioxidant, anti-inflammatory, anticancer, antidiabetic, and cardio-protective effects and widely used in the development of different traditional medicines for the treatment of diseases. It is also well known to have good effects on anti-angiogenesis, anti-metastasis, anti-inflammation, and estrogenic regulation and can regulate many signal pathways. Besides, luteolin is considered to have potential clinical value for cancer prevention and therapies. Luteolin can obstruct the later stages of the DENV viral life cycle in infected cells by inhibiting the host proprotein convertase furin. Luteolin also exhibits inhibitory effects on EpsteinBarr Virus, Japanese encephalitis virus, HIV-1, Hepatitis B virus, Hepatitis C virus, enterovirus 71, coxsackievirus A16, and chikungunya virus (Table 5).

\subsection{Isorhamnetin}

Isorhamnetin (Iso) is a flavonoid compound extracted from the Chinese herb Hippophae rhamnoides L. Previous studies have revealed its anticancer, anti-inflammatory, and antioxidant activities. What's notable here is the antiviral activity of isorhamnetin. Oral administration of isorhamnetin in mice infected with the influenza A virus significantly decreased lung virus titer by 2 -folds and decreased the virus titer in vivo using embryonated chicken eggs. Structure-activity 
Table 4 Anti-virus activity of apigenin

\begin{tabular}{|c|c|c|c|}
\hline Virus & Mechanism of action & Dose/concentration & References \\
\hline EBV & $\begin{array}{l}\text { Inhibits expression of EBV lytic proteins, Zta, Rta, EAD, and } \\
\text { DNase }\end{array}$ & $\begin{array}{r}200 \text { to } 295 \mu \mathrm{M}(24 \mathrm{~h}) \\
69 \text { to } 158 \mu \mathrm{M}(48 \mathrm{~h})\end{array}$ & An et al. [56] \\
\hline African swine fever virus & $\begin{array}{l}\text { Inhibits ASFV-specific protein synthesis and viral factory forma- } \\
\text { tion }\end{array}$ & IC50:212.1 $\pm 11.5 \mu \mathrm{M}$ & Hakobyan et al. [57] \\
\hline $\mathrm{HCV}$ & $\begin{array}{l}\text { Inhibits HCV replication by decreasing mature miR122 expres- } \\
\text { sion }\end{array}$ & $5 \mu \mathrm{M}$ & Shibata et al. [58] \\
\hline SARS-CoV 3CL pro & Inhibits SARS-CoV 3CL pro & $280.8 \mu \mathrm{M}$ & Ryu et al. [59] \\
\hline PEDV & Interferes PEDV replication & & Choi et al. [60] \\
\hline FMD virus & Inhibits cytopathogenic effect and FMDV replication & & Qian et al. [61] \\
\hline HIV & Inhibits CYP3A4, slowdown elimination of PIs & & Kehinde et al. [62] \\
\hline Influenza virus & & $1.43 \mu \mathrm{g} / \mathrm{mL}$ & Liu et al. [51] \\
\hline Vaccinia virus & Inhibits VV replication & & Chang et al. [63] \\
\hline PV-2 & & $12.2-13.3 \mu \mathrm{M}$ & Visintini Jaime et al. [64] \\
\hline
\end{tabular}

relationship (SAR) showed the methyl group located on the $\mathrm{B}$ ring of isorhamnetin might contribute to its strong antiviral potency against the influenza virus in comparison with other flavonoids. In addition, isorhamnetin treatment reduced virus-induced ROS generation and blocked cytoplasmic lysosome acidification and the lipidation of microtubule associated protein1 light chain 3-B (LC3B). The evidence for the anti-virus activity of isorhamnetin was shown in Table 6.

\subsection{Isoflavone}

Isoflavones are polyphenolic secondary plant metabolites that are produced primarily from members of the Leguminosae. There are hundreds of naturally occurring isoflavones isolated and identified. Common isoflavones include daidzin, genistin, biochanin A, and formononetin. All isoflavones share the 3-phenylchromen-4-one backbone, which is always modified, mainly by $\mathrm{O}$-substituents, glycosides, and/or prenylated derivatives. In plants consumed as part of the human diet (including dietary supplements), the highest concentrations of isoflavones have been observed in soy (Glycine max

Table 5 Anti-virus activity of luteolin

\begin{tabular}{|c|c|c|c|}
\hline Virus & Mechanism of action & Dose/concentration & References \\
\hline DENV & Inhibits proprotein convertase furin & $\begin{array}{l}10 \mathrm{mM} \\
100 \mathrm{mg} / \mathrm{kg}\end{array}$ & Peng et al. [65] \\
\hline EBV & $\begin{array}{l}\text { Inhibits viral lytic proteins expression } \\
\text { and interferes with Sp1 binding to } \\
\text { the IE gene promoters }\end{array}$ & $\begin{array}{l}\text { NA cells }(\text { IC } 50=8.6-18.1 \mu \mathrm{M}) ; \mathrm{HA} \\
\text { cells }(\mathrm{IC} 50=6-12.3 \mu \mathrm{M}) ; \mathrm{B} \text { cells } \\
(\mathrm{IC} 50=6-8 \mu \mathrm{M})\end{array}$ & Wu et al. [66] \\
\hline Japanese Encephalitis Virus (JEV) & Inhibits JEV replication & $\mathrm{IC} 50=4.56 \mu \mathrm{g} / \mathrm{mL}$ & Fan et al. [67] \\
\hline Influenza virus $\mathrm{A} / \mathrm{Jinan} / 15 / 90(\mathrm{H} 3 \mathrm{~N} 2)$ & Inhibits neuraminidase (NA) activities & IC50 $=7.15 \mu \mathrm{M}$ & Liu et al. [51] \\
\hline $\begin{array}{l}\text { Influenza virus A/Jiangxi/312/2006 } \\
\text { (H3N2) } \\
\text { A/Fort Monmouth/1/1947 (H1N1) }\end{array}$ & $\begin{array}{l}\text { Interferes with the virus at the early } \\
\text { stages of its lifecycle and blocks } \\
\text { influenza virus absorption and } \\
\text { internalization }\end{array}$ & $\mathrm{IC} 50=6.89 \mu \mathrm{M}$ & Yan et al. [68] \\
\hline HBV & $\begin{array}{l}\text { Inhibits HBV transcription through } \\
\text { ERK-mediated downregulation of } \\
\text { HNF4 } \alpha \text { expression }\end{array}$ & $10-40 \mu \mathrm{M} ; 2 \mathrm{mg} / \mathrm{kg}$ & Bai et al. [69] \\
\hline HIV-1 & $\begin{array}{l}\text { Inhibits HIV-1 activity; infection } \\
\text { by abrogating Tat-mediated LTR } \\
\text { activity }\end{array}$ & $5-10 \mu \mathrm{M}$ & Mehla et al. [70] \\
\hline SARS-CoV & $\begin{array}{l}\text { Binds to the surface spike protein of } \\
\text { SARS-CoV and inhibits entry of the } \\
\text { virus into host cells }\end{array}$ & $\mathrm{EC} 50=10.6 \mu \mathrm{M}$ & Yi et al. [71] \\
\hline COVID-19 & $\begin{array}{l}\text { Inhibits COVID-19 main protease } \\
\text { Mpro }\end{array}$ & & Khaerunnisa et al. [72] \\
\hline
\end{tabular}


L.), red clover (Trifolium pratense), and kudzu. Isoflavones exhibit antioxidant, anticancer, antimicrobial, anti-inflammatory, antiosteoporotic, and estrogenic properties. Especially, isoflavones and their related flavonoid compounds exert antiviral properties both in vitro and in vivo against a wide range of viruses. Targets of Isoflavones reported affecting virus binding, entry, replication, viral protein translation, and formation of certain virus envelope glycoprotein complexes. Isoflavones also affect a variety of host cell signaling processes, including induction of gene transcription factors and secretion of cytokines (Table 7).

\subsection{Catechin/EGCG (Epigallocatechin-3-gallate)}

Catechins are important ingredients from tea leaves and account for more than $75 \%$ of the polyphenol compounds in tea leaves. Catechins are members of the group of polyphenol compounds found in many medicinal plants, with a anti-oxidant and representative physiological activities. The major sources of catechins are Camellia sinensis $(C$. sinensis) and $C$. assumica. There are eight catechin: $\mathrm{C}((-)$-catechin), EC ((-)-epicatechin), ECG ((-)-epicatechingallate), EGC ((-)-epigallocatechin), EGCG ((-)-epigallocatechin gallate), GC ((-)-gallocatechin), CG ((-)-catechingallate), and GCG ((-)-gallocatechingallate). Because of the hydroxyl in the gallate group, Epigallocatechin-3-O-gallate (EGCG) and ECG are highly effective free-radical scavengers compared with many other standard anti-oxidants. According to the relationships between structure and antiviral activity of catechin derivatives, the 3-galloyl and 5'-OH group of catechin derivatives appear critical to antiviral activities. Most Catechin/EGCG were reported not to affect cell viability and proliferation but interfered with herpes simplex virus cell penetration and adhesion. Among these catechins, EGCG is the major catechin component of green tea (Cameria sinensis) and known to possess antiviral activi-

Table 6 Anti-virus activity of isorhamnetin

\begin{tabular}{lllll}
\hline Virus & Mechanism of action & Dose/concentration & In vitro/in vivo & References \\
\hline $\begin{array}{l}\text { EV71 virus } \\
\text { H1N1 virus }\end{array}$ & $\begin{array}{l}\text { Inhibits EV71 RNA replication and protein synthesis } \\
\text { Reduces virus-induced active oxygen production, blocking } \\
\text { cytoplasmic lysosomal acidification and lipid formation } \\
\text { of microtubule-associated proteins }\end{array}$ & $10 \mathrm{mg} / \mathrm{kg}$ & $\begin{array}{l}\text { In vivo } \\
\text { In vivo }\end{array}$ & Dai et al. [73] \\
EHVhtaivan et al. [74] \\
$\begin{array}{l}\text { HHV2 virus } \\
\text { Zika virus }\end{array}$ & $\begin{array}{l}\text { between cells and viruses } \\
\text { Inhibits NS3-NS2B protease }\end{array}$ & $100 \mathrm{~g} / \mathrm{mL}$ & In vitro & Sochocka et al. [75] \\
\hline
\end{tabular}

Table 7 Anti-virus activity of isoflavones

\begin{tabular}{|c|c|c|c|c|}
\hline Isoflavone & Virus & Mechanism of action & Dose/concentration & References \\
\hline \multirow[t]{2}{*}{ Genistein } & Avian leucosis virus & $\begin{array}{l}\text { Inhibits the late phase of ALV-J replica- } \\
\text { tive cycle }\end{array}$ & $12.5-100 \mu \mathrm{M}$ & Qian et al. [77] \\
\hline & $\begin{array}{l}\text { Porcine reproductive and respiratory syn- } \\
\text { drome virus (PRRSV) }\end{array}$ & $\begin{array}{l}\text { Activation of adaptive immune system } \\
\text { pathways }\end{array}$ & & Smith et al. [78] \\
\hline Genistein & African swine fever virus & $\begin{array}{l}\text { Disrupts viral DNA replication, block- } \\
\text { ing the transcription of late viral genes } \\
\text { as well as the synthesis of late viral } \\
\text { proteins, reducing viral progeny }\end{array}$ & $\mathrm{IC}_{50}=13 \mu \mathrm{M}$ & Arabyan et al. [79] \\
\hline Genistein & rotavirus & $\begin{array}{l}\text { Inhibits rotavirus replication and upregu- } \\
\text { lates AQP4 expression }\end{array}$ & $80 \mu \mathrm{M}$ & Huang et al. [80] \\
\hline Genistein & Herpes simplex virus & Inhibits virus replication & $40 \mu \mathrm{M}$ & Argenta et al. [81] \\
\hline KIN 101 & $\begin{array}{l}\text { hepatitis } \mathrm{C} \text { virus (HCV) and influenza } \\
\text { virus }\end{array}$ & $\begin{array}{l}\text { Activates the ISG54 promoter mediated } \\
\text { nuclear translocation of IRF-3 }\end{array}$ & $\mathrm{IC}_{50}=0.2 \mu \mathrm{M}$ & Bedard et al. [82] \\
\hline \multirow[t]{2}{*}{ Deguelin } & Human cytomegalovirus (HCMV) & $\begin{array}{l}\text { Suppresses the production of the infec- } \\
\text { tious virus; inhibits the lytic cycle }\end{array}$ & $250 \mathrm{nM}$ & Nukui et al. [83] \\
\hline & HIV-1 & $\begin{array}{l}\text { Inhibits HIV-1 entry into cell lines, pri- } \\
\text { mary human } \mathrm{CD}^{+} \mathrm{T} \text { lymphocytes, and } \\
\text { macrophages }\end{array}$ & $\mathrm{IC}_{50}=81.6 \pm 4.3 \mu \mathrm{M}$ & Mediouni et al. [84] \\
\hline Daidzein & Dengue virus type-2 & Inhibits virus replication & $\mathrm{IC}_{50}=142.6 \mu \mathrm{g} / \mathrm{mL}$ & Zandi et al. [43] \\
\hline
\end{tabular}

ring and the basic structure of flavan-3-ol and have intensive ties against a wide range of DNA viruses and RNA viruses. 
Table 8 Anti-virus activity of catechin/EGCG

\begin{tabular}{|c|c|c|c|c|}
\hline Catechin & Virus & Mechanism of action & Dose/concentration & References \\
\hline EGCG & HBV & $\begin{array}{l}\text { Detrimental to HBV replication by } \\
\text { altering lysosomal acidification }\end{array}$ & $25-50 \mu \mathrm{M}$ & Zhong et al. [85] \\
\hline $\begin{array}{l}\text { EC, ECG, } \\
\text { EGC and } \\
\text { EGCG }\end{array}$ & HSV-1/HSV-2 & $\begin{array}{l}\text { Destructive HSV-1 } \\
\text { virions;competitively interacted } \\
\text { with virion surface proteins }\end{array}$ & $\begin{array}{l}\text { HSV1:IC99 } \\
\left(\mathrm{IC}_{50}: 18.3-72.3 \mu \mathrm{M}\right) \\
\mathrm{HSV}_{2}: \mathrm{IC}_{99} \\
\left(\mathrm{IC}_{50}: 12.5-25 \mu \mathrm{M}\right)\end{array}$ & $\begin{array}{l}\text { Isaacs et al. [86] } \\
\text { Colpitts et al. [87] }\end{array}$ \\
\hline EGCG & EBV & $\begin{array}{l}\text { Suppressed the synthesis of lytic } \\
\text { protein; inhibited the lytic infec- } \\
\text { tion; reducing the DNA binding } \\
\text { potency of nuclear antigen; inhibi- } \\
\text { tion of the MEK/ERK1/2 and } \\
\text { PI3-K/Akt signaling pathways }\end{array}$ & $\mathrm{IC}_{50}: 250 \mu \mathrm{M}$ & $\begin{array}{l}\text { Weber et al. [88] } \\
\text { Liu et al. [89] }\end{array}$ \\
\hline EGCG & Adenovirus & $\begin{array}{l}\text { Inhibited the attachment of adeno- } \\
\text { virus by interacting with virion } \\
\text { surface proteins }\end{array}$ & $\mathrm{IC}_{50}: 20 \mu \mathrm{M}$ & Liu et al. [90] \\
\hline $\begin{array}{l}\text { EGCG, EC } \\
\text { ECG }\end{array}$ & HIV1/HIV2 & $\begin{array}{l}\text { Inhibitory action against HIVRT; } \\
\text { competitive inhibitors of the } \\
\text { template-primer; noncompetitive } \\
\text { inhibitors of Dttp; inhibits HIV } \\
\text { entry }\end{array}$ & $\begin{array}{c}\text { EGCG:300 mg/kg/day; } \\
\text { IC50:3.44 } \pm 1.07 \mu \mathrm{M} \\
\text { GCG:2.45 } \pm 0.36 \mu \mathrm{M}\end{array}$ & $\begin{array}{l}\text { Yamaguchi et al. [91] } \\
\text { Hartjen et al. [92] } \\
\text { Rrapo et al. [93] }\end{array}$ \\
\hline EGCG & $\mathrm{HCV}$ & $\begin{array}{l}\text { Inhibitor of the } \mathrm{HCV} \text { entry and viral } \\
\text { RNA replication }\end{array}$ & $\mathrm{IC}_{50}: 17.9 \mu \mathrm{M}$ & Chen et al. [94] \\
\hline $\begin{array}{l}\text { EGCG, EC } \\
\text { ECG }\end{array}$ & Influenza $\mathrm{A} / \mathrm{B}$ & $\begin{array}{l}\text { Inhibitory effects on the acidifica- } \\
\text { tion of endosomes and lysosomes; }\end{array}$ & $\begin{array}{l}\text { EC: }>145.09 \mu \mathrm{g} / \mathrm{mL} \\
\text { EGC: } 30.49 \mu \mathrm{g} / \mathrm{mL} \\
\text { EGCG: } 56.49 \mu \mathrm{g} / \mathrm{mL}\end{array}$ & $\begin{array}{l}\text { Imanishi [95] } \\
\text { Yang et al [96] }\end{array}$ \\
\hline EGCG & DENV, JEV and TBEV & $\begin{array}{l}\text { Associated with the DENV2 E pro- } \\
\text { tein; destruction of the structure of } \\
\text { ZIKV virions }\end{array}$ & $>100 \mu \mathrm{M}$ & Carneiro et al. [97] \\
\hline EGCG & $\begin{array}{l}\text { Human T-cell Lymphotropic Virus- } \\
1\end{array}$ & $\begin{array}{l}\text { Reduce the invasive potential of } \\
\text { HTLV-1-positive leukemia cells; } \\
\text { suppressing Tax expression; } \\
\text { inhibiting the activation of NF-kB } \\
\text { pathway and induction of MMP-9 } \\
\text { transcription in HTLV-1 positive } \\
\text { cells }\end{array}$ & $25 \mu \mathrm{M}$ in HuT-102 & Harakeh et al. [98] \\
\hline $\begin{array}{l}\text { EGCG } \\
\text { GCC }\end{array}$ & Rotaviruses enteroviruses & $\begin{array}{l}\text { Interfering with virus adsorption; } \\
\text { reduced reactive oxygen species } \\
\text { (ROS) generation }\end{array}$ & GCG: $10 \mu \mathrm{M}$ EGCG: $10 \mu \mathrm{M}$ & Ho et al. [99] \\
\hline EGCG & Ebola virus (EBOV) & $\begin{array}{c}\text { Reduced the production of new } \\
\text { viruses via inhibiting HSPS5 }\end{array}$ & $10-100 \mu \mathrm{M}$ & Reid et al. [100] \\
\hline
\end{tabular}

EGCG has been reported to possess a broad spectrum of antiviral activities against DNA viruses such as herpes simplex virus (HSV; Herpesviridae) adenovirus (Adenoviridae), human papilloma virus (HPV; Papovaviridae), and hepatitis B virus (HBV; Hepadnaviridae), and against (+)-RNA viruses such as hepatitis $\mathrm{C}$ virus (HCV; Flaviviridae), Zika virus (ZIKV; Flaviviridae), dengue virus (DENV; Flaviviridae), West Nile viruses (WNV; Flaviviridae), Chikungunya virus (CHIKV; Togaviridae), and Porcine Reproductive and Respiratory virus (PRRS; Atteriviridae), and (-)RNA viruses such as human immunodeficiency virus (HIV; Retroviridae), Ebola virus (EBOV; Filoviridae) and influenza virus (Table 8 ).

\section{Conclusion}

The study of flavonoids is complex because of the heterogeneity of the different molecular structures and the scarcity of data on bioavailability. An important effect of flavonoids is the scavenging of oxygen-derived free radicals. Flavonoids possess anti-inflammatory, antiallergic, antiviral, and anticarcinogenic properties from the evidence obtained in vitro experimental systems. However, the clinical application of flavonoids is restricted by its low solubility and poor bioavailability. Although there are lots of advances in the antiviral pharmacology of natural flavonoids, further study is needed to elucidate the effects of flavonoids within the body 
and the degree and rate of absorption for the evaluation of druggability.

With the development of preparation techniques, newly developed flavonoids preparations exhibit better absorption and thus have higher bioavailability. Since flavonoids are frequently prescribed with other medications, understanding the compatibility of co-administrated drugs is of importance for clinical applications, and requires further research for better clarity. Furthermore, pharmacokinetic changes of flavonoids under different pathological conditions indicate clinical considerations of drug safety and the possible requirement of individualized antiviral therapy.

Acknowledgements The work was supported by CAMS Innovation Fund for Medical Sciences (Grant No. 2017-I2M-1-010); National Key Research and Development Program (Grant No. 2018YFC0311005); National Science and Technology Major Projects (Grant No. 2018ZX09711001-012).

\section{Compliance with Ethical Standards}

Conflict of interest All authors declare no conflict of interest.

Open Access This article is licensed under a Creative Commons Attribution 4.0 International License, which permits use, sharing, adaptation, distribution and reproduction in any medium or format, as long as you give appropriate credit to the original author(s) and the source, provide a link to the Creative Commons licence, and indicate if changes were made. The images or other third party material in this article are included in the article's Creative Commons licence, unless indicated otherwise in a credit line to the material. If material is not included in the article's Creative Commons licence and your intended use is not permitted by statutory regulation or exceeds the permitted use, you will need to obtain permission directly from the copyright holder. To view a copy of this licence, visit http://creativecommons.org/licenses/by/4.0/.

\section{References}

1. L.H. Cazarolli, L. Zanatta, E.H. Alberton, M.S. Figueiredo, P. Folador, R.G. Damazio, M.G. Pizzolatti, F.R. Silva, Flavonoids: prospective drug candidates. Mini. Rev. Med. Chem. 8(13), 1429-1440 (2008)

2. A.N. Panche, A.D. Diwan, S.R. Chandra, Flavonoids: an overview. J. Nutr. Sci. 5, e47 (2016)

3. L. Gao, M. Zu, S. Wu, A.L. Liu, G.H. Du, 3D QSAR and docking study of flavone derivatives as potent inhibitors of influenza H1N1 virus neuraminidase. Bioorg. Med. Chem. Lett. 21(19), 5964-5970 (2011)

4. G.B. Gonzales, In vitro bioavailability and cellular bioactivity studies of flavonoids and flavonoid-rich plant extracts: questions, considerations and future perspectives. Proc. Nutr. Soc. 76(3), 175-181 (2017)

5. S. Kumar, A.K. Pandey, Chemistry and biological activities of flavonoids: an overview. Sci. World J. 2013, 162750 (2013)

6. H. Zakaryan, E. Arabyan, A. Oo, K. Zandi, Flavonoids: promising natural compounds against viral infections. Adv. Virol. 162(9), 2539-2551 (2017)
7. S. Jo, S. Kim, D.H. Shin, M.S. Kim, Inhibition of SARS-CoV 3CL protease by flavonoids. J. Enzyme Inhib. Med. Chem. 35(1), 145-151 (2020)

8. Q. Zhao, Y. Zhang, G. Wang, L. Hill, J.K. Weng, X.Y. Chen, H. Xue, C. Martin, A specialized flavone biosynthetic pathway has evolved in the medicinal plant, Scutellariabaicalensis. Sci. Adv. 2(4), e1501780 (2016)

9. K. Kawabata, Y. Yoshioka, J. Terao, Role of intestinal microbiota in the bioavailability and physiological functions of dietary polyphenols. Molecules (Basel, Switzerland) 24(2), 370 (2019)

10. K. Murota, Y. Nakamura, M. Uehara, Flavonoid metabolism: the interaction of metabolites and gut microbiota. Biosci. Biotechnol. Biochem. 82(4), 600-610 (2018)

11. P.C. Hollman, M.N. Bijsman, Y. van Gameren, E.P. Cnossen, J.H. de Vries, M.B. Katan, The sugar moiety is a major determinant of the absorption of dietary flavonoid glycosides in man. Free Radical Res. 31(6), 569-573 (1999)

12. H.S. Huang, C.G. Ma, Z.W. Chen, Advances in the research on pharmacological actions of flavone compounds. Zhongguo Zhong yao za $\mathrm{zhi}=$ Zhongguo zhongyao zazhi $=$ China journal of Chinese materia medica 25(10), 589-592 (2000)

13. L.R. de Sousa, H. Wu, L. Nebo, J.B. Fernandes, M.F. da Silva, W. Kiefer, M. Kanitz, J. Bodem, W.E. Diederich, T. Schirmeister, P.C. Vieira, Flavonoids as noncompetitive inhibitors of Dengue virus NS2B-NS3 protease: inhibition kinetics and docking studies. Bioorg. Med. Chem. 23(3), 466-470 (2015)

14. B. Ozcelik, M. Kartal, I. Orhan, Cytotoxicity, antiviral and antimicrobial activities of alkaloids, flavonoids, and phenolic acids. Pharm. Biol. 49(4), 396-402 (2011)

15. P. Sithisarn, M. Michaelis, M. Schubert-Zsilavecz, J. Cinatl Jr., Differential antiviral and anti-inflammatory mechanisms of the flavonoids biochanin A and baicalein in H5N1 influenza A virusinfected cells. Antiviral Res. 97(1), 41-48 (2013)

16. J.F. Shimizu, C.S. Lima, C.M. Pereira, C. Bittar, M.N. Batista, A.C. Nazare, C.R. Polaquini, C. Zothner, M. Harris, P. Rahal, L.O. Regasini, A.C.G. Jardim, Flavonoids from Pterogynenitens inhibit hepatitis C virus entry. Sci. Rep. 7(1), 16127 (2017)

17. M.P. Nair, C. Kandaswami, S. Mahajan, K.C. Chadha, R. Chawda, H. Nair, N. Kumar, R.E. Nair, S.A. Schwartz, The flavonoid, quercetin, differentially regulates Th-1 (IFNgamma) and Th-2 (IL4) cytokine gene expression by normal peripheral blood mononuclear cells. Biochem. Biophys. Acta. 1593(1), 29-36 (2002)

18. M.J. Bae, H.S. Shin, H.J. See, S.Y. Jung, D.A. Kwon, D.H. Shon, Baicalein induces CD4(+)Foxp3(+) T cells and enhances intestinal barrier function in a mouse model of food allergy. Sci. Rep. 6, 32225 (2016)

19. A.L. Liu, B. Liu, H.L. Qin, S.M. Lee, Y.T. Wang, G.H. Du, Anti-influenza virus activities of flavonoids from the medicinal plant Elsholtziarugulosa. Planta Med. 74(8), 847-851 (2008)

20. M. Yonekawa, M. Shimizu, A. Kaneko, J. Matsumura, H. Takahashi, Suppression of R5-type of HIV-1 in CD4(+) NKT cells by Vdelta1(+) T cells activated by flavonoid glycosides, hesperidin and linarin. Sci. Rep. 9(1), 7506 (2019)

21. J.T. Ortega, M.L. Serrano, A.I. Suarez, J. Baptista, F.H. Pujol, L.V. Cavallaro, H.R. Campos, H.R. Rangel, Antiviral activity of flavonoids present in aerial parts of Marcetiataxifolia against hepatitis B virus, poliovirus, and herpes simplex virus in vitro. EXCLI J. 18, 1037-1048 (2019)

22. R.Y. Mekky, N. El-Ekiaby, S.A. El Sobky, N.M. Elemam, R.A. Youness, M. El-Sayed, M.T. Hamza, G. Esmat, A.I. Abdelaziz, Epigallocatechin gallate (EGCG) and miR-548m reduce HCV entry through repression of CD81 receptor in $\mathrm{HCV}$ cell models. Adv. Virol. 164(6), 1587-1595 (2019) 
23. S. Nzuza, S. Zondi, P.M.O. Owira, Naringin prevents HIV-1 protease inhibitors-induced metabolic complications in vivo. PLoS ONE 12(11), e0183355 (2017)

24. A.K. Patra (ed.), Dietary phytochemicals and microbes (Springer, Dordrecht, 2012), pp. 93-126

25. T. Li, L. Liu, H. Wu, S. Chen, Q. Zhu, H. Gao, X. Yu, Y. Wang, W. Su, X. Yao, T. Peng, Anti-herpes simplex virus type 1 activity of Houttuynoid A, a flavonoid from Houttuyniacordata Thunb. Antiviral Res. 144, 273-280 (2017)

26. C. Bus, N. Kusz, G. Jakab, S.A. Senobar Tahaei, I. Zupko, V. Endresz, A. Bogdanov, K. Burian, B. Csupor-Loffler, J. Hohmann, A. Vasas, Phenanthrenes from Juncuscompressus Jacq. with promising antiproliferative and anti-HSV-2 activities. Molecules 23(8), 2085 (2018)

27. J. Dou, L. Chen, G. Xu, L. Zhang, H. Zhou, H. Wang, Z. Su, M. $\mathrm{Ke}, \mathrm{Q}$. Guo, C. Zhou, Effects of baicalein on Sendai virus in vivo are linked to serum baicalin and its inhibition of hemagglutininneuraminidase. Adv. Virol. 156(5), 793-801 (2011)

28. S. O’Neill, R.K. Porter, N. McNamee, V.G. Martinez, L. O'Driscoll, 2-Deoxy-D-glucose inhibits aggressive triple-negative breast cancer cells by targeting glycolysis and the cancer stem cell phenotype. Sci. Rep. 9(1), 3788 (2019)

29. M. Granato, M.S. Gilardini Montani, C. Zompetta, R. Santarelli, R. Gonnella, M.A. Romeo, G. D'Orazi, A. Faggioni, M. Cirone, Quercetin interrupts the positive feedback loop between STAT3 and IL-6, promotes autophagy, and reduces ROS, preventing EBV-driven B cell immortalization. Biomolecules 9(9), 482 (2019)

30. C. Zhang, N. Li, F. Niu, Baicalein triazole prevents respiratory tract infection by RSV through suppression of oxidative damage. Microb. Pathog. 131, 227-233 (2019)

31. S.M. Lipson, G. Karalis, L. Karthikeyan, F.S. Ozen, R.E. Gordon, S. Ponnala, J. Bao, W. Samarrai, E. Wolfe, Mechanism of anti-rotavirus synergistic activity by epigallocatechin gallate and a proanthocyanidin-containing nutraceutical. Food Environ. Virol. 9(4), 434-443 (2017)

32. H. Liu, F. Ye, Q. Sun, H. Liang, C. Li, R. Lu, B. Huang, W. Tan, L. Lai, Scutellariabaicalensis extract and baicalein inhibit replication of SARS-CoV-2 and its 3C-like protease in vitro. bioRxiv (2020). https://doi.org/10.1101/2020.04.10.035824

33. P. Mohammadi Pour, S. Fakhri, S. Asgary, M.H. Farzaei, J. Echeverria, The signaling pathways, and therapeutic targets of antiviral agents: focusing on the antiviral approaches and clinical perspectives of anthocyanins in the management of viral diseases. Front. Pharmacol. 10, 1207 (2019)

34. J. Adams, N. Patel, N. Mankaryous, M. Tadros, C.D. Miller, Nonnucleoside reverse transcriptase inhibitor resistance and the role of the second-generation agents. Ann. Pharmacother. 44(1), 157-165 (2010)

35. M. Aarthy, S.K. Singh, Discovery of potent inhibitors for the inhibition of dengue envelope protein: an in silico approach. Curr. Top. Med. Chem. 18(18), 1585-1602 (2018)

36. A. Prussia, P. Thepchatri, J.P. Snyder, R.K. Plemper, Systematic approaches towards the development of host-directed antiviral therapeutics. Int. J. Mol. Sci. 12(6), 4027-4052 (2011)

37. M.J. Hour, S.H. Huang, C.Y. Chang, Y.K. Lin, C.Y. Wang, Y.S. Chang, C.W. Lin, Baicalein, ethyl acetate, and chloroform extracts of Scutellariabaicalensis inhibit the neuraminidase activity of pandemic $2009 \mathrm{H} 1 \mathrm{~N} 1$ and seasonal influenza A viruses. Evid. Based Complemen. Altern. Med. 2013, 750803 (2013)

38. A.L. Liu, H.D. Wang, S.M. Lee, Y.T. Wang, G.H. Du, Structureactivity relationship of flavonoids as influenza virus neuraminidase inhibitors and their in vitro anti-viral activities. Bioorg. Med. Chem. 16(15), 7141-7147 (2008)
39. C. Li, J.S. Fang, W.W. Lian, X.C. Pang, A.L. Liu, G.H. Du, In vitro antiviral effects and $3 \mathrm{D}$ QSAR study of resveratrol derivatives as potent inhibitors of influenza H1N1 neuraminidase. Chem. Biol. Drug Des. 85(4), 427-438 (2015)

40. Y. Marunaka, Actions of quercetin, a flavonoid, on ion transporters: its physiological roles. Ann. N. Y. Acad. Sci. 1398(1), 142-151 (2017)

41. C.D.S. Mello, L.M.M. Valente, T. Wolff, R.S. Lima-Junior, L.G. Fialho, C.F. Marinho, E.L. Azeredo, L.M. Oliveira-Pinto, R.C.A. Pereira, A.C. Siani, C.F. Kubelka, Decrease in dengue virus-2 infection and reduction of cytokine/chemokine production by Uncaria guianensis in human hepatocyte cell line Huh-7. Mem. Inst. Oswaldo Cruz 112(6), 458-468 (2017)

42. R.S. Barboza, L.M.M. Valente, T. Wolff, I. Assuncao-Miranda, R.L.S. Neris, I.P. Guimaraes-Andrade, M. Gomes, Antiviral activity of Farameahyacinthina and Farameatruncata leaves on dengue virus type- 2 and their major compounds. Chem. Biodivers. 15(2), 1700393 (2018)

43. K. Zandi, B.T. Teoh, S.S. Sam, P.F. Wong, M.R. Mustafa, S. Abubakar, Antiviral activity of four types of bioflavonoid against dengue virus type-2. Virol. J. 8, 560 (2011)

44. P. Kumar, M. Khanna, V. Srivastava, Y.K. Tyagi, H.G. Raj, K. Ravi, Effect of quercetin supplementation on lung antioxidants after experimental influenza virus infection. Exp. Lung Res. 31(5), 449-459 (2005)

45. J. Johari, A. Kianmehr, M.R. Mustafa, S. Abubakar, K. Zandi, Antiviral activity of baicalein and quercetin against the Japanese encephalitis virus. Int. J. Mol. Sci. 13(12), 16785-16795 (2012)

46. S. Ganesan, A.N. Faris, A.T. Comstock, Q. Wang, S. Nanua, M.B. Hershenson, U.S. Sajjan, Quercetin inhibits rhinovirus replication in vitro and in vivo. Antiviral Res. 94(3), 258-271 (2012)

47. A.E. dos Santos, R.M. Kuster, K.A. Yamamoto, T.S. Salles, R. Campos, M.D. de Meneses, M.R. Soares, D. Ferreira, Quercetin and quercetin 3-O-glycosides from Bauhinialongifolia (Bong.) Steud. show anti-Mayaro virus activity. Parasites Vectors 7, 130 (2014)

48. W. Wu, R. Li, X. Li, J. He, S. Jiang, S. Liu, J. Yang, Quercetin as an antiviral agent inhibits influenza A virus (IAV) entry. Viruses 8(1), 6 (2015)

49. M. Lee, M. Son, E. Ryu, Y.S. Shin, J.G. Kim, B.W. Kang, H. Cho, H. Kang, Quercetin-induced apoptosis prevents EBV infection. Oncotarget 6(14), 12603-12624 (2015)

50. A. Rojas, J.A. Del Campo, S. Clement, M. Lemasson, M. GarciaValdecasas, A. Gil-Gomez, I. Ranchal, B. Bartosch, J.D. Bautista, A.R. Rosenberg, F. Negro, M. Romero-Gomez, Effect of quercetin on hepatitis $\mathrm{C}$ virus life cycle: from viral to host targets. Sci. Rep. 6, 31777 (2016)

51. Z. Liu, J. Zhao, W. Li, L. Shen, S. Huang, J. Tang, J. Duan, F. Fang, Y. Huang, H. Chang, Z. Chen, R. Zhang, Computational screen and experimental validation of anti-influenza effects of quercetin and chlorogenic acid from traditional Chinese medicine. Sci. Rep. 6, 19095 (2016)

52. G. Xu, J. Dou, L. Zhang, Q. Guo, C. Zhou, Inhibitory effects of baicalein on the influenza virus in vivo is determined by baicalin in the serum. Biol. Pharma. Bull. 33(2), 238-243 (2010)

53. E. Moghaddam, B.T. Teoh, S.S. Sam, R. Lani, P. Hassandarvish, Z. Chik, A. Yueh, S. Abubakar, K. Zandi, Baicalin, a metabolite of baicalein with antiviral activity against dengue virus. Sci. Rep. 4, 5452 (2014)

54. M.J. Wang, C.H. Yang, Y. Jin, C.B. Wan, W.H. Qian, F. Xing, X. Li, Y.Y. Liu, Baicalin inhibits coxsackievirus B3 replication by reducing cellular lipid synthesis. Am. J. Chin. Med. 48(1), 143-160 (2020)

55. M.R. Fesen, Y. Pommier, F. Leteurtre, S. Hiroguchi, J. Yung, K.W. Kohn, Inhibition of HIV-1 integrase by flavones, caffeic 
acid phenethyl ester (CAPE) and related compounds. Biochem. Pharmacol. 48(3), 595-608 (1994)

56. C.C. Wu, C.Y. Fang, Y.J. Cheng, H.Y. Hsu, S.P. Chou, S.Y. Huang, C.H. Tsai, J.Y. Chen, Inhibition of Epstein-Barr virus reactivation by the flavonoid apigenin. J. Biomed. Sci. 24(1), 2 (2017)

57. A. Hakobyan, E. Arabyan, A. Avetisyan, L. Abroyan, L. Hakobyan, H. Zakaryan, Apigenin inhibits African swine fever virus infection in vitro. Adv. Virol. 161(12), 3445-3453 (2016)

58. C. Shibata, M. Ohno, M. Otsuka, T. Kishikawa, K. Goto, R. Muroyama, N. Kato, T. Yoshikawa, A. Takata, K. Koike, The flavonoid apigenin inhibits hepatitis $\mathrm{C}$ virus replication by decreasing mature microRNA122 levels. Virology 462-463, 42-48 (2014)

59. Y.B. Ryu, H.J. Jeong, J.H. Kim, Y.M. Kim, J.Y. Park, D. Kim, T.T. Nguyen, S.J. Park, J.S. Chang, K.H. Park, M.C. Rho, W.S. Lee, Biflavonoids from Torreyanucifera displaying SARS-CoV 3CL(pro) inhibition. Bioorg. Med. Chem. 18(22), 7940-7947 (2010)

60. H.J. Choi, J.H. Kim, C.H. Lee, Y.J. Ahn, J.H. Song, S.H. Baek, D.H. Kwon, Antiviral activity of quercetin 7-rhamnoside against porcine epidemic diarrhea virus. Antiviral Res. 81(1), 77-81 (2009)

61. S. Qian, W. Fan, P. Qian, D. Zhang, Y. Wei, H. Chen, X. Li, Apigenin restricts FMDV infection and inhibits viral IRES driven translational activity. Viruses 7(4), 1613-1626 (2015)

62. I. Kehinde, P. Ramharack, M. Nlooto, M. Gordon, The pharmacokinetic properties of HIV-1 protease inhibitors: a computational perspective on herbal phytochemicals. Heliyon 5(10), e02565 (2019)

63. C.-W. Chang, H.-C. Li, C.-F. Hsu, C.-Y. Chang, S.-Y. Lo, Increased ATP generation in the host cell is required for efficient vaccinia virus production. J. Biomed. Sci. 16(1), 80-80 (2009)

64. M.F. Visintini Jaime, F. Redko, L.V. Muschietti, R.H. Campos, V.S. Martino, L.V. Cavallaro, In vitro antiviral activity of plant extracts from Asteraceae medicinal plants. Virol. J. 10(1), 245 (2013)

65. M. Peng, S. Watanabe, K.W.K. Chan, Q. He, Y. Zhao, Z. Zhang, X. Lai, D. Luo, S.G. Vasudevan, G. Li, Luteolin restricts dengue virus replication through inhibition of the proprotein convertase furin. Antiviral Res. 143, 176-185 (2017)

66. C.C. Wu, C.Y. Fang, H.Y. Hsu, Y.J. Chen, S.P. Chou, S.Y. Huang, Y.J. Cheng, S.F. Lin, Y. Chang, C.H. Tsai, J.Y. Chen, Luteolin inhibits Epstein-Barr virus lytic reactivation by repressing the promoter activities of immediate-early genes. Antiviral Res. 132, 99-110 (2016)

67. W. Fan, S. Qian, P. Qian, X. Li, Antiviral activity of luteolin against Japanese encephalitis virus. Virus Res. 220, 112-116 (2016)

68. H. Yan, L. Ma, H. Wang, S. Wu, H. Huang, Z. Gu, J. Jiang, Y. $\mathrm{Li}$, Luteolin decreases the yield of influenza A virus in vitro by interfering with the coat protein I complex expression. J. Nat. Med. 73(3), 487-496 (2019)

69. L. Bai, Y. Nong, Y. Shi, M. Liu, L. Yan, J. Shang, F. Huang, Y. Lin, H. Tang, Luteolin inhibits hepatitis B virus replication through extracellular signal-regulated kinase-mediated downregulation of hepatocyte nuclear factor 4alpha expression. Mol. Pharm. 13(2), 568-577 (2016)

70. R. Mehla, S. Bivalkar-Mehla, A. Chauhan, A flavonoid, luteolin, cripples HIV-1 by abrogation of tat function. PLoS ONE 6(11), e27915 (2011)

71. L. Yi, Z. Li, K. Yuan, X. Qu, J. Chen, G. Wang, H. Zhang, H. Luo, L. Zhu, P. Jiang, L. Chen, Y. Shen, M. Luo, G. Zuo, J. Hu, D. Duan, Y. Nie, X. Shi, W. Wang, Y. Han, T. Li, Y. Liu, M. Ding, H. Deng, X. Xu, Small molecules blocking the entry of severe acute respiratory syndrome coronavirus into host cells. J. Virol. 78(20), 11334-11339 (2004)

72. T.C. Theoharides, COVID-19, pulmonary mast cells, cytokine storms, and beneficial actions of luteolin, BioFactors (England, Oxford, 2020)

73. W. Dai, J. Bi, F. Li, S. Wang, X. Huang, X. Meng, B. Sun, D. Wang, W. Kong, C. Jiang, W. Su, Antiviral efficacy of flavonoids against enterovirus 71 infection in vitro and in newborn mice. Viruses 11(7), 625 (2019)

74. G. Enkhtaivan, K.M. Maria John, M. Pandurangan, J.H. Hur, A.S. Leutou, D.H. Kim, Extreme effects of Seabuckthorn extracts on influenza viruses and human cancer cells and correlation between flavonol glycosides and biological activities of extracts. Saudi J. Biol. Sci. 24(7), 1646-1656 (2017)

75. M. Sochocka, M. Sobczynski, M. Ochnik, K. Zwolinska, J. Leszek, Hampering herpesviruses HHV-1 and HHV-2 infection by extract of Ginkgobiloba (EGb) and its phytochemical constituents. Front. Microbiol. 10, 2367 (2019)

76. S. Bhargava, T. Patel, R. Gaikwad, U.K. Patil, S. Gayen, Identification of structural requirements and prediction of inhibitory activity of natural flavonoids against Zika virus through molecular docking and Monte Carlo based QSAR simulation. Nat. Prod. Res. 33(6), 851-857 (2019)

77. K. Qian, A.J. Gao, M.Y. Zhu, H.X. Shao, W.J. Jin, J.Q. Ye, A.J. Qin, Genistein inhibits the replication of avian leucosis virus subgroup J in DF-1 cells. Virus Res. 192, 114-120 (2014)

78. B.N. Smith, A. Morris, M.L. Oelschlager, J. Connor, R.N. Dilger, Effects of dietary soy isoflavones and soy protein source on response of weanling pigs to porcine reproductive and respiratory syndrome viral infection. J. Anim. Sci. 97(7), 2989-3006 (2019)

79. E. Arabyan, A. Hakobyan, A. Kotsinyan, Z. Karalyan, V. Arakelov, G. Arakelov, K. Nazaryan, A. Simonyan, R. Aroutiounian, F. Ferreira, H. Zakaryan, Genistein inhibits African swine fever virus replication in vitro by disrupting viral DNA synthesis. Antiviral Res. 156, 128-137 (2018)

80. H. Huang, D. Liao, L. Liang, L. Song, W. Zhao, Genistein inhibits rotavirus replication and upregulates AQP4 expression in rotavirus-infected Caco-2 cells. Adv. Virol. 160(6), 1421-1433 (2015)

81. D.F. Argenta, I.T. Silva, V.L. Bassani, L.S. Koester, H.F. Teixeira, C.M. Simoes, Antiherpes evaluation of soybean isoflavonoids. Adv. Virol. 160(9), 2335-2342 (2015)

82. K.M. Bedard, M.L. Wang, S.C. Proll, Y.M. Loo, M.G. Katze, M. Gale Jr., S.P. Iadonato, Isoflavone agonists of IRF-3 dependent signaling have antiviral activity against RNA viruses. J. Virol. 86(13), 7334-7344 (2012)

83. M. Nukui, C.M. O'Connor, E.A. Murphy, The natural flavonoid compound deguelin inhibits HCMV lytic replication within fibroblasts. Viruses 10(11), 614 (2018)

84. S. Mediouni, J.A. Jablonski, S. Tsuda, A. Richard, C. Kessing, M.V. Andrade, A. Biswas, Y. Even, T. Tellinghuisen, H. Choe, M. Cameron, M. Stevenson, S.T. Valente, Potent suppression of HIV-1 cell attachment by Kudzu root extract. Retrovirology 15(1), 64 (2018)

85. L. Zhong, J. Hu, W. Shu, B. Gao, S. Xiong, Epigallocatechin3-gallate opposes HBV-induced incomplete autophagy by enhancing lysosomal acidification, which is unfavorable for HBV replication. Cell Death Dis. 6(5), e1770 (2015)

86. C.E. Isaacs, G.Y. Wen, W. Xu, J.H. Jia, L. Rohan, C. Corbo, V. Di Maggio, E.C. Jenkins Jr., S. Hillier, Epigallocatechin gallate inactivates clinical isolates of herpes simplex virus. Antimicrob. Agents Chemother. 52(3), 962-970 (2008)

87. C.C. Colpitts, L.M. Schang, A small molecule inhibits virion attachment to heparan sulfate- or sialic acid-containing glycans. J. Virol. 88(14), 7806-7817 (2014) 
88. J.M. Weber, A. Ruzindana-Umunyana, L. Imbeault, S. Sircar, Inhibition of adenovirus infection and adenain by green tea catechins. Antiviral Res. 58(2), 167-173 (2003)

89. S. Liu, H. Li, L. Chen, L. Yang, L. Li, Y. Tao, W. Li, Z. Li, H. Liu, M. Tang, A.M. Bode, Z. Dong, Y. Cao, (-)-Epigallocatechin-3-gallate inhibition of Epstein-Barr virus spontaneous lytic infection involves ERK1/2 and PI3-K/Akt signaling in EBVpositive cells. Carcinogenesis 34(3), 627-637 (2013)

90. S. Liu, H. Li, L. Chen, L. Yang, L. Li, Y. Tao, W. Li, Z. Li, H. Liu, M. Tang, A.M. Bode, Z. Dong, Y. Cao, (-)-Epigallocatechin-3-gallate inhibition of Epstein-Barr virus spontaneous lytic infection involves ERK1/2 and PI3-K/Akt signaling in EBVpositive cells. Carcinogenesis 34(3), 627-637 (2012)

91. K. Yamaguchi, M. Honda, H. Ikigai, Y. Hara, T. Shimamura, Inhibitory effects of (-)-epigallocatechin gallate on the life cycle of human immunodeficiency virus type 1 (HIV-1). Antiviral Res. 53(1), 19-34 (2002)

92. P. Hartjen, S. Frerk, I. Hauber, V. Matzat, A. Thomssen, B. Holstermann, H. Hohenberg, W. Schulze, J. Schulze Zur Wiesch, J. van Lunzen, Assessment of the range of the HIV-1 infectivity enhancing effect of individual human semen specimen and the range of inhibition by EGCG. AIDS Res. Ther. 9(1), 2 (2012)

93. E. Rrapo, Y. Zhu, J. Tian, H. Hou, A. Smith, F. Fernandez, J. Tan, B. Giunta, Green Tea-EGCG reduces GFAP associated neuronal loss in HIV-1 Tat transgenic mice. Am. J. Transl. Res. 1(1), 72-79 (2009)

94. C. Chen, H. Qiu, J. Gong, Q. Liu, H. Xiao, X.W. Chen, B.L. Sun, R.G. Yang, (-)-Epigallocatechin-3-gallate inhibits the replication cycle of hepatitis C virus. Adv. Virol. 157(7), 1301-1312 (2012)
95. M.W. Roomi, R.J. Jariwalla, T. Kalinovsky, N. Roomi, A. Niedzwiecki, M. Rath, Inhibition of cellular invasive parameters in influenza A virus-infected MDCK and Vero cells by a nutrient mixture. BioFactors (Oxford, England) 33(1), 61-75 (2008)

96. Z.F. Yang, L.P. Bai, W.B. Huang, X.Z. Li, S.S. Zhao, N.S. Zhong, Z.H. Jiang, Comparison of in vitro antiviral activity of tea polyphenols against influenza $A$ and $B$ viruses and structure-activity relationship analysis. Fitoterapia 93, 47-53 (2014)

97. B.M. Carneiro, M.N. Batista, A.C.S. Braga, M.L. Nogueira, P. Rahal, The green tea molecule EGCG inhibits Zika virus entry. Virology 496, 215-218 (2016)

98. S. Harakeh, M. Diab-Assaf, R. Azar, H.M. Hassan, S. Tayeb, K. Abou-El-Ardat, G.A. Damanhouri, I. Qadri, A. Abuzenadah, A. Chaudhary, T. Kumosani, A. Niedzwiecki, M. Rath, H. Yacoub, E. Azhar, E. Barbour, Epigallocatechin-3-gallate inhibits taxdependent activation of nuclear factor kappa B and of matrix metalloproteinase 9 in human T-cell lymphotropic virus-1 positive leukemia cells. Asian Pac. J. Cancer Prev. 15(3), 1219-1225 (2014)

99. H.Y. Ho, M.L. Cheng, S.F. Weng, Y.L. Leu, D.T. Chiu, Antiviral effect of epigallocatechin gallate on enterovirus 71. J. Agric. Food Chem. 57(14), 6140-6147 (2009)

100. S.P. Reid, A.C. Shurtleff, J.A. Costantino, S.R. Tritsch, C. Retterer, K.B. Spurgers, S. Bavari, HSPA5 is an essential host factor for Ebola virus infection. Antiviral Res. 109, 171-174 (2014) 